\title{
New Literacy Opportunities and Practices of Latino/a Children of Poverty In and Out of School
}

\author{
KATHY M. BUSSERT-WEBB \\ University of Texas Brownsville \\ MARIA E. DIAZ \\ University of Texas Brownsville
}

\begin{abstract}
This case study examines new literacy opportunities and practices of 28 Latino/a children from grades one to seven in a South Texas colonia, or unincorporated area. Data sources were 24-hour literacy logs, two rounds of interviews, and participant observations. The children reported limited school work related to digital literacies; the technology they accessed outside of school focused on entertainment, communication with friends, and mostly non-challenging video games. We discuss participants' ingenious ways of circumventing any lack of access, their underlying social practices of community sharing, and Thirdspace possibilities of the tutorial center that respondents attended.
\end{abstract}

\section{Introduction}

This article focuses on the digital literacy practices of 28 Latino/a children in a South Texas colonia, or unincorporated area where city services are non-existent (U.S. Department of Housing and Urban Development, 2005). The poverty rate for Hispanic children is $33.1 \%$ (U.S. Census Bureau, 2010). As researchers have not explored Latino/a children's new literacy practices in Texas colonias, which constitute at least 500,000 people along the Mexican border (Brenner, Coronado, \& Solden, 2003), our study asks what digital technology access Latino/a children of poverty have in and out of school and how they use digital technology. What Thirdspace (Soja, 1996) possibilities are available for them? These questions are significant because Latinos are the fastest growing U.S. ethnic group and many Latino/a children face economic challenges.

The digital divide is not just about tools, but also the interrelationship between experiences, dispositions, and ever-changing skills in and out of school (Leu, Zawilinsky, Castek, Banerjee, Housand, Liu, \& O’Neil, 2007; Pahl \& Rowsell, 2005). Although teachers in a national survey gave low socio-economic status (SES) youth more computer access than high SES students, the computer tasks of the former focused on low-level use (Becker, 2000). Thus, to give digital technology more power, we frame it as a literacy issue in hopes that educational policies will include the use of information and communication technologies (ICTs) in and out of school (Leu, O'Byrne, Zawilinski, McVerry, \& Everett-Cacopardo, 2009). We perceive digital technology as part of new literacy practices (Gee, 2007); indeed, literacy and digital technology inform each other (Karchmer, Mallette, Kara-Soteriou, \& Leu, 2005). This is because "literacy is a malleable repertoire of practices" related to social transformation (Luke, 2005, p. xi). 
Digital literacies are "socially situated practices supported by skills, strategies, and stances that enable the representation and understanding of ideas using a range of modalities enabled by digital tools" (O'Brien \& Scharber, 2008, pp. 66-67). Digital literacy tools include ICTs, video games, wireless inter-interfaces (Wiis), PlayStation portables (PSPs), dual-screen games (DSis and DSs), and other hand-held devices (Skudowitz, 2009). Information and communication lines are transactional because one can find information on an iPhone, iPad, or DSi and can play a game with someone using another DS. Digital literacies also involve meaning making and collaboration (Kalantzis, 2011).

\section{Theoretical Perspectives}

Theoretical perspectives utilized in this study include reconstructionism, New Literacy Studies (NLS) traditions, and funds of knowledge. Reconstructionism was a lens because of systemic inequalities related to colonia residents (Freire, 1970) and a focus on transformation (Janks, 2010). Access relates to reconstructionism in terms of structural resources available for children of poverty (Becker, 2000; Lazarus, Wainer, \& Lipper, 2005). We also studied the use of new literacies, and underlying social inequalities reproduced in that use because literacy relates to domination and power (Janks). For instance, teachers from high SES districts were more likely to assign Internet-related homework than districts serving students of poverty; also, teachers and students from wealthy districts had significantly higher mean scores on online reading comprehension (Henry, 2007). Thus, we included design as ways children can circumvent inequalities; design is the "production of texts that use multiple sign systems" (Janks, p. 18). Yet, like Fernández (2001), we perceive a text as anything made by humans; texts can include paperclips (Janks), ICTs, conversations, and art.

As part of reconstructionism, we include spatial justice (Soja, 2010, 2011); although some spaces can be unfair to diverse children of poverty, other spaces, such as the tutorial center participants attended, can engage youth in transformative practices. Moje, Ciechanowski, Kramer, Ellis, Carrillo, and Collazo (2004) posit Thirdspace is also possible in schools when teachers affirm and extend youths' Discourses, or sociallysituated identities (Gee, 2008) with generative disciplinary practices. Firstspace includes homes, peers, and neighborhoods and Secondspace includes formal institutions, such as schools and business, or high-power spheres (Moje et al., 2004). Thirdspace represents an alternative for other spaces to complement each other and to transform hybridized practices (Soja, 1996). Thus, instead of binaries, Thirdspace is about deconstruction and reconstruction (Frink, Ares, Mukhopadhyay, \& Tsoumani, 2010).

Because of its political nature, NLS relates to reconstructionism; Luke (2005) discusses the NLS commitment to "education as a force for a more equitable redistribution of social goods, power, and capital" (p. xiii). Also, we perceive literacy practices as ideological, not neutral, and as contextualized (Barton \& Hamilton, 1998; Gee, 2000b; Street, 1993, 2003). Although literacy events are part of NLS, we did not examine moments of composing and comprehending print; instead we focused on practices, or "patterns of activity around literacy" (Pahl \& Rowsell, 2005, p. 155). Hence, we compare non-dominant, informal practices outside of school and dominant literacies in school (Barton \& Hamilton, 1998; Street \& Lefstein, 2007). Our research is part of the 
overarching NLS theory because we interpret use of cell phones, hand-held games, and other ICTs to enhance literacy practices (Gee, 2007; Stolle, 2008). Indeed, digital literacies involve multimodalities, skills, contexts, and practices (Pahl \& Rowsell, 2005; Street \& Lefstein, 2007). Although NLS conceptualizations have undergone many changes, Luke (2005) reminds us the field is not about theorists, but instead about "change in the material world of social life and practice" (p. xii); NLS has evolved because of the hybridity of cultures and languages and the crucial role digital literacies play in the lives of many children.

A related theoretical perspective was funds of knowledge, which Greenberg (1990) coined to signify culturally developed bodies of knowledge and skills needed for individuals or families to thrive. Social relationships that facilitate the exchange of knowledge, skills, and goods are funds of knowledge (Moll, 1992). This framework helps us to understand how and why participants shared digital literacies. Moll (1992) states, "The less access to formal sectors, the greater the reliance of households on reciprocal networks for survival" (p. 228). Also, we discuss the colonia's positive aspects to counter a deficit model, prevalent in literature about culturally diverse children of poverty (González, Moll, \& Amanti, 2005; Gorski, 2008).

\section{Setting}

This study took place in a South Texas colonia, pseudonym Esperanza. With approximately 6,000 residents and nearly 50 years of existence, it is the oldest and largest U.S. colonia settlement with about $99 \%$ Hispanics and $97 \%$ native Spanish speakers (U.S. Census Bureau, 2000). Esperanza residents share many socio-economic and environmental challenges with other colonias, including few basic services and housing infrastructures and a lack of access to public transportation and affordable health care (Texas Secretary of State, 2010). Esperanza is the poorest of all U.S. communities for its size, with a per capita income of approximately $\$ 4,000$ and median household income of less than $\$ 17,000$. Esperanza residents have a high drop-out rate, also. Among residents of 25 years and over, $10 \%$ have a high school degree (or equivalent), and $2 \%$ have obtained a bachelor's degree (U.S. Census Bureau, 2000).

Despite these challenges, most Esperanza children attend schools that are Texas Education Agency (TEA) recognized or exemplary, based on attendance, retention rates, and results on state-mandated tests (Long, 2010). Esperanza residents have a strong practice of sharing, which is essential, given the economic struggles of most residents. According to Moll (1992), "The exchange of funds of knowledge...is a major strategy to deal with the lack of resources, a strategy developed to harness, control, and manipulate resources" (p. 227). For example, one can see orange extension cords between homes so neighbors can split utility costs. Parents volunteer at the research site and help children with homework; prepare and serve snacks; and plant and water flora by the center. The research setting was an after-school tutorial center, where up to 30 children, in grades first through ninth, have attended to receive homework assistance. The program, in existence for over 12 years, has offered outdoor recreation and educational field trips, also. 


\section{Methods}

This institutionally-approved case study is part of a larger project in which Latino/a teacher candidates have tutored, and gardened with, Esperanza children since 2006 (Bussert-Webb, 2008, 2009a, 2009b). Participants were 28 children, 14 boys and 14 girls, ages six to 14 , and in grades first through seven. Twenty-two children attended primary school, while six were enrolled in middle school. Ninety-six percent completed 24-hour literacy $\operatorname{logs}$ in their language of preference. The log, comprised of five questions, focused on children's self-reports of reading while getting ready, during school, to and from school, for homework, and during free time. For this paper, we only discuss responses related to digital literacies.

In May 2010 we interviewed 26 children in a tutorial classroom. We interviewed two friends or siblings together to make them comfortable and to save time; the program lasted only three weeks Most of the 30-minute audio-taped interviews were Spanish and English combinations, depending on respondents' preferences. The structured interviews consisted of demographics and questions about the tutoring and gardening program, reading, and digital literacy experiences. The latter questions focused on whether participants used computers and cell phones; where and how often they used them; and access to ICTs.

Participants' digital literacy responses piqued our interest, so we interviewed $50 \%$ of the initial respondents; many 2010 participants were no longer attending the tutorials. To avoid the methodological problem of respondents providing the same information as peers, we interviewed each one privately. Questions for these semi-structured interviews related to: texting; use of cell phones, games, ICTs, and computers in and out of school; ownership and negotiated use; functioning home computers and Internet; Internet speed; experiences with school projects related to digital literacies; how participants felt about the ways they used digital literacies; and where a person could go to access ICTs free of charge. A sample question was: "What have been your experiences with technologyrelated school projects?" Toward the end of each second interview, we conducted cell phone and laptop think alouds; like Damico and Baildon (2007), we sought to determine participants' purposes and text-processing. The protocol was: "Here is a cell phone/computer. Please tell me what you're doing and your purposes for using it." Follow-up questions pertained to where participants navigated, what they were doing, and why.

Included in methods are our six years of participant-observations at the tutorial center where we have observed the children using digital literacies alone and with others. Analysis of literacy logs and interview transcriptions consisted of looking for patterns and was based on grounded theory (Glaser \& Strauss, 1967). Individually, we read all data and jotted down key words, phrases, or sentences used by respondents. Also, we interpreted interview responses and literacy logs by writing key ideas or concepts beside data. Next, we read through the data again and continued the process of jotting down participants' words and our insights. We identified and categorized data by making comparisons and looking for similarities (Bogdan \& Biklin, 2007). Some initial themes were sharing, creativity, and lack of access to digital literacies. 


\section{Results}

Based on data analysis, we identified three themes: digital literacy use in school and for school-related work, out-of-school digital literacy access, and everyday digital literacy purposes.

\section{Digital Literacy Use in School and for School-related Homework}

Few participants used computers for authentic purposes in school and few had technology-related assignments. Only $27 \%$ of the first set of interviewees and $30 \%$ of the second set reported using school computers. This is corroborated by the literacy log, in which 7\% mentioned school computer use. However, many reported visiting school libraries weekly to check out AR books (mostly novels), to take computer tests on them, or to receive prizes based on points accrued. Some statements regarding AR tests were: "It is fun, "cause I like to test in the computer when I read books," and "Uso la Internet en la biblioteca para hacer AR books y no más eso", [I use the school Internet for AR, and nothing else].

From both interview sets only a few mentioned conducting Internet searches related to topics of their choice. When Friv, 12, did not comprehend her teachers, she searched the Internet for clarification. However, it was not clear where she searched or if she was looking up vocabulary or concepts: "Hay cosas que me dicen que no entiendo y busco en el Internet", [Sometimes they tell me things I do not understand, and then I search in the Internet]. Although she used the Internet to understand subjects not explained well, her queries were extra-curricular. Flor, 13, explained inquiry was not emphasized in her technology-related assignments: "In school we do assignments the teacher tells us to do, like calendars and vocabulary words and some companies [referring to the stock market]. This is in technology class."

When asked what types of technology-related assignments they have had, only two participants reported having experienced several:

Cariñosa, 11: Smelly science. It's about they need to put cologne and perfume, which one smells much faster [sic]. You can type what you need to vote. You first vote on a piece of paper and then you copy it on the computer. It's an experiment.

Frank, 13: I'm doing a PowerPoint and I like that. It's about body parts, your respiratory system. I copy and paste the interactions ... It's for science.

Cadamayo, 13, and Flor discuss the paucity of technology-based assignments:

You have to pick the president you like the most. Well Obama, 'cause I don't know the rest. Find information, when he was born, how many years does he have being [sic] the president, his family, how many sons or daughters, where he lived. I did a PowerPoint.

I can't remember, but I do know we did a project. I had to look up information on the Internet in sixth grade. They made me use the computer for Christmas, like we had to make a list about what we wanted for Christmas. We sent it through the 
computer to the teacher. It was a technology class. I didn't do more than this in classes.

It appeared the holiday wish list was composed quickly and during class because lists do not involve much recursive writing usually; also, it appeared everyone sent their lists to the instructor during that period. Indeed, most, like PSP, eight, never have had homework related to digital literacies: "No, no me mandan tarea para las computadoras. Lo hago en el centro, pero no lo uso la computadora para proyectos", [No, I do not have homework to do with computers. I do my homework at the tutorial center, but I do not use the computers to do projects].

When asked how they felt about their digital literacy use, most expressed an affinity for digital literacies. Hermanito, 12, stated: "If the world didn't have technology, everything would be boring for me because I won't have nothing [sic] to do." Cariñosa said: "[I feel] awesome because back then we didn't have it and now we're starting to have it." Flor expressed anger about a lack of digital literacy integration:

We haven't done projects. I get mad because you don't do that. In other schools they might do that and we don't ... Like some other classes, they do PowerPoints about songs and in our class we don't do that, like write about a person you admire. I would stay after school and work on it, if it was a technology project, or go to the public library ... At school I would like to use more technology. I would like to have a laptop and we would have to use it in every single period.

Cadamayo, 13, and Friv did not have time to use digital literacies because they had too much non-technology-based homework. However, like most participants, they wanted more because they liked doing projects. Most participants wanted more digital assignments, such as PowerPoints, creating their own videos, and family trees.

In this section, we discussed participants' paucity of technology-related work, yet their desire for more. Although some did research projects, most engaged in low-level, linear technology use, involving creating lists, copying and pasting, and taking multiple choice tests. Those who engaged in technology did so outside of the curriculum.

\section{Digital Literacy Access Outside of School}

We found Esperanza's tutorial center was far more popular for accessing technology than the public libraries. The libraries, over two miles from Esperanza, had several free computers with high-speed Internet. Also, most participants had home computers and Internet and used both daily for non-academic purposes. Those without computers, the Internet, and hand-held devices tapped into social relationships in the colonia to post photos, text, and play games.

Most (89\%) used computers at the tutorial center. The center appeared to be a place for those without Internet, computers, or printers. Primeracomunión, 10, stated: "En mi casa no tengo Internet y cuando me mandan averiguar algo para la escuela lo hago aquí, en el centro de tutorías ... Tenía [Internet] pero no la pudimos pagar”, [In my home I don't have the Internet and when they make me find something in school I do it here, at the tutorial center ... We had Internet, but we couldn't pay for it]. 
Francisca, 13, had home computers, but accessed those in the center as well because of their affinities: "Si [uso las computadoras en el centro] para hacer un 'journal' para aqui, también para jugar, también Internet”, [Yes, I use the computers at the center to write a journal, also to play and to use the Internet]. Francisca was referring to the new tutorial center activity in which children in grades five and up had three choices: read, do homework, or type a personal response in a laptop to one of three questions staff members pose.

Some participants did not know where to get hardware issues repaired. Flor stated, "The big computer has a virus, but we don't know where to go to fix it." Knowing the resourcefulness of respondents and their families, we assume if they would have had friends or families who knew how to repair computers or to clear computers of viruses, they would have asked for help.

Although respondents could not find people to repair computers, many circumvented costly video games. They showed us free games during their laptop think alouds. Artista, nine, explained: "They're for free where it's in the normal games. When you click here [going to the start button], it's going to say games." During her think aloud, Cadamayo went to friv.com, which had at least 50 free games, including SpongeBob and Mario. Bussert-Webb asked, "But don't they ask you to start paying, like \$3.00 a month?" Cadamayo said when she wants to play, she types free first: "First you put [sic] type in 'free typing games.' That's the website."

Another way participants circumvented any lack of access was through sharing. Francisca explained how she shared computers and games at home: "La computadora es una laptop. La comparto con mi hermana y con mi hermano. No nos peleamos porque cada uno tiene una hora para usarla. Mi mamá pone la hora”, [The computer is a laptop. I share it with my sister and brother. We do not argue, since everyone has a time to use it. My mother sets the schedule].

Only one owned a cell phone, but about half accessed those of friends and family. Fútbol and Cynthia, both 13, said: "No tengo, pero lo uso para [I don't have one, but I use it to] call my friends" and "A veces uso el de [staff member] para escuchar música", [Sometimes I use (name) to listen to music]. Some may not have used a cell phone because they perceived themselves (or their family perceived them) to be too young.

Another example of social networking occurred one day after conducting interviews. Primeracomunión asked Bussert-Webb to take Primeracomunión's photo and to send it to her email so she could put it on her profile page in Facebook; her mother did not have a digital camera or cell phone camera. Participants tapped into other personal relationships to gain access to digital literacies as well. When asked where a person with no digital technology at home could use computers with Internet, respondents' most common responses were: the tutorial center, the homes of friends and family, their schools, and public libraries. Less common responses were: fast food restaurants, Internet cafes, and Best Buy (an electronics store). This resourcefulness and collaboration demonstrated that regardless of economic difficulties, participants would find ways to use the digital technology they deemed as relevant. The close-knit community in which they lived also facilitated the exchange of resources (Moll, 1992). Indeed, they used their funds of knowledge to circumvent any lack of access. 
Yet, most participants had access; $69 \%$ of the first set of interviewees had computers and $62 \%$ used the Internet at home. In the second round, $83 \%$ had computers and rapid Internet. Usage is corroborated by the logs, in which $59 \%$ mentioned engaging in Internet-related activities outside of school. Because the log question was about reading during free time, not specifically digital literacies, their answers demonstrate interest in the latter. The majority accessed a computer for 45 minutes daily, mostly away from school.

We did not ask about hand-held devices for gaming in the first interview, but in the second interview, 54\% played daily on these hand-held devices: DS, DSi, PS3, PSP, and Xbox; Luchalibre, 10, used a PS3, Xbox, and PSP daily. His brother, Frank, used an Xbox 360 for three hours per day and a PS3 two hours daily; others did not specify how many hours daily they played games on these hand-held devices, but all seven used them daily at home. All but one interviewee said these devices were their siblings; one owned her own DS. One child wrote in his literacy log that he went to a neighbor's house to play computer games.

In summary, most participants had working home computers and high-speed Internet; those without these tools accessed them in their neighborhood. The tutorial center in Esperanza was an important technology site. Also, those who did not own handheld devices and games used collaboration and resourcefulness to gain access.

\section{Purposes for Digital Literacy Use Outside of School}

Most participants did not play complex video games, nor did they appear to strategize or collaborate much during the gaming process. Although a few used Facebook or Myspace on a regular basis to communicate with friends and family, the majority accessed video games. Also, it appeared older siblings, such as Luchalibre's brother and Flor's sister, influenced participants' digital literacy use, and that these older family members accessed technology for friendship and consumption. Most participants accessed computers and hand-held devices to play music and games, to text, and to call others; few used technology for academic purposes.

Primary school respondents played 16 games, including: Sesame Street; Plants vs. Zombies; Poptropica; Purble Place; InkBall; Bejeweled 2 Deluxe; Cake Mania 1 and 2; billiards; and chess. When asked which games were the hardest, Artista, nine, responded: "Plants vs. Zombies, 'cause some buckethead zombies and football player zombies. They're hard to kill. You have to use the repeater in order to kill them." Middle school interviewees reported playing at least 27 games, including: Crash, Zombie Farm, Sonic, Littlest PetShop, Mario Brothers 64, Sift Heads, Hello Kitty, World of Warcraft, CrimeCity, Pirates Ahoy!, Texas Hold'em Poker, Wild Ones, and SpongeBob.

Chess and World at War appeared to allow for more imagination, collaboration, and complex thinking processes (Gee, 2007), yet much depends on what one does in the gaming process. Although we did not ask them how they strategized, it did not appear most played complex, collaborative games, or that they looked up information to play more strategically (Gee, 2009, 2011). Juego, eight, responded: "I just use normal games like Zombieland here in the computers, not Internet games." However, Luchalibre and Frank, who were brothers, played games from the Call of Duty series, such as World at 
War, which is more challenging and open-ended, because of multiple strategies to complete objectives.

Several elementary and middle school participants went to Google, Facebook, friv.com, buzzbeegames.com, megamind.com, and other free sites. Frank accessed a game in Facebook in which friends gave him fake money to play. Bussert-Webb saw the words "help me and red dice," which related to gambling. When we handed the primary school children our laptops during the think aloud process, 92\% went to games immediately, either online or the free ones that came in our laptops. However, after games, two emailed others. Artista, nine, said: "I also go to Facebook right there." [She typed Facebook.com, then her email and password]. "I find my friends. I will send them emails and play games."

Even though middle school respondents reported playing at least 27 games, when we handed them our laptops, only $15 \%$ went to games immediately. Flor appeared to go to websites for entertainment and fashion: "I go to Google and I look for pictures of Wisin y Yandel. They're a Puerto Rican Reggaeton duo and look for other famous people and play games ... I go to videojuegos.com. My sister told me about it. When I used to have Internet at home, I'd go and play dress up. You can dress up people. [Bussert-Webb: "That's in Spanish. Can you read it?"] "I can read Spanish and I look at the pictures, and I would go to Converse and create. Something will pop up and I will click on it and I would design a shoe. My sister told me about this, too."

Later we visited Flor's dress-up and music sites, and we realized the thinking skills required in navigating maps appeared far more complex. One site appeared to be a place to look at cute animals in costumes and the Wisin y Yandel site was about consumption in the entertainment industry. Interestingly, Flor's older sister told her about the "animals dressed up" site. We believe older siblings influenced the younger ones' web surfing and game choices, which allows for the sharing of semiotic resources. However, for the most part, the older siblings reproduced practices focused on consumption.

Indeed, most used computers for consumption, friendship, and entertainment; 69\% of the first and second round of interviewees used the Internet to play games, listen to music, email or chat with friends, or use Facebook or Myspace. In their logs, only 8\% used computers for academic projects outside of school - one third grader and one fifth grader. Francisca said: "La uso para hacer trabajo, también para Myspace, y a veces texteo con mi prima. Tengo e-mail y mando e-mail a mis 'friends', 'cousins' y a mi tía", [I use it to do work, also for Myspace, and sometimes I chat with my cousin. I have email and I send email to my friends, cousins, and aunt]. We did not ask what she meant by work, but we assumed she was referring to school.

During the cell phone think alouds, $86 \%$ of the middle schoolers used a cell phone to text, but no primary school participant texted. In the log, $15 \%$ reported texting at least once daily. Two middle school students used the cell to call others and one to listen to music. Other cell phone uses were playing games and accessing the Internet. During the cell phone think aloud, Primeracomunión said, "First I check if it has Internet. I will go to Myspace or Facebook. I will put a picture." She did not have the Internet at home, but used her cell phone often for Internet access. Participants texted mostly their friends, and sometimes their mothers. 
We found digital literacies were an important part of participants' lives outside of school, but their digital literacy experiences had little or no relationship to academics. Also, their digital use was mostly friendship-based, versus interest-based, and it was for mostly consumption, versus creation. Although older siblings influenced participants, this influence appeared to replicate a dearth of complex digital literacy knowledge and skills.

\section{Discussion}

Access, purpose, and use of digital literacies in and out of school are theorized in this section.

\section{Digital Literacy Use in School and for Assignments}

Participants' digital literacy use in school appeared to be for low-level work involving little creativity and effort. Examples were Flor's Christmas wish list and participants' countless AR tests. They seemed to have little choice and ownership, which appears to parallel the curriculum in schools with predominantly Latino/a children of poverty. For example, Bussert-Webb (2009c) interviewed children attending a highlyrated public primary school serving mostly low SES Latinos. She found the 47 children had little control of their school day: "Powerlessness seemed to embody life for these low-income Latino/a students in an "exemplary' school" (p. 52). This lack of student autonomy is in sharp contrast to the curriculum most wealthy white students' experience. In a study of 300 tracked high school mathematics and English classrooms, Oakes (2005) found teachers in lower-track classes focused on worksheets, memorization, rote learning, and conforming to classroom rules and expectations. However, teachers of advanced courses "were more likely to emphasize such behaviors as critical thinking, active participation, self-direction, and creativity" (p. 85). High SES white students tended to be in advanced classes and low-income students of color were invariably in lower-tracked ones. The systemic differences in opportunity between races and social classes are structural inequalities (Enterline, Cochran-Smith, Ludlow, \& Mitescu, 2008).

As Lankshear and Knobel (2006) state, new literacies involve new "technical stuff" and "ethos stuff." The latter relates to collaborative, participatory, distributed social practices, such as shared decision making and problem solving. New literacies do not mean merely typing and emailing lists, as one participant mentioned, or taking multiple choice exams on a computer, which countless participants reported. Instead, Lankshear and Knobel suggest we consider how new technologies can support and extend social practices.

Few participants reported using a computer at school; most use appeared to be extracurricular. Participants attended campuses offering free breakfast and lunch to all students; thus, their schools are considered to be high-poverty. Although $93 \%$ of kindergarten through grade 12 U.S. classrooms have Internet access (Parsad, Jones, \& Green, 2005), Internet use is not common in most U.S. schools (Cuban, 2001). The exception is schools serving predominately wealthy students. Lazarus, Wainer, and Lipper (2005) discovered 63\% of children from household incomes of over \$75,000 used the Internet at school, versus $36 \%$ of low SES children (less than $\$ 15,000$ per household). In a national survey teachers of predominantly low-income students reported weekly computer use more often than those of high-income students (Becker, 2000); however, 
tasks for the former students focused on repetitive practice, while those for the latter were for "sophisticated intellectually complex applications" (p. 44).

Although Google.com and yahoo.com websites are available in schools Esperanza children attend, district officials block many other websites, including teachertube.com, apparently to protect children from accessing inappropriate information. Hand-held devices, games, and gaming magazines, such as Game Informer, are prohibited, also. If teachers want to hook disenfranchised students with music, videos, and other forms of digital literacies for classes, they cannot do so. As Leu, McVerry, et al. (2009) state, a rich child gets richer with enriching and challenging technologies and a poor child gets ... Left Behind. This discrepancy is exacerbated by the lack of high-level technology mentoring that participants have received outside of school. If older family members and peers have not experienced interest-based digital literacies to create things, it follows their digital literacy use would influence the young participants.

When asked how they felt about their digital literacy use in and out of school, most had no complaints. We realized we should have asked two separate questions: one about digital literacy satisfaction in school and another about out-of-school satisfaction. This is because many participants wanted more technology-based assignments. Some, like Cadamayo and Friv, had too much non-technology based homework, which prevented them from engaging in digital literacy outside of school. It struck us as odd participants' teachers segregated assignments from digital literacies. Unfortunately, it appeared their teachers may have perceived homework and digital literacies as mutually exclusive, yet they can, and should exist interdependently to prepare students for the $21^{\text {st }}$ century (Gee, 2011).

Flor's expression of anger about digital technology was significant. She had not done technology-related projects, but said students in other schools engaged in them often and in meaningful ways. She would stay after school and work on digital projects or go to the public library to do so. It appeared as if she was saying, "Give me the challenging work and I will find the tools to complete it." This reminds us of a homeless high school student in another study (K. Haycock, personal communication, December 17, 2003). Haycock asked the student what she needed to achieve academically. Instead of mentioning food and shelter, the student said she wanted her teachers to believe she was capable and to provide her with challenging curricula.

Flor, like Haycock's respondent, wanted teachers to engage her in a challenging curriculum. Also, she wanted to use a laptop in every class period; however, no participant reported having laptops in schools. The Tutors with Computers experience of Flor's sister appeared to be an anomaly. It seemed Flor realized inequalities and desired change. Janks' (2010) orientation to critical literacy includes four interdependent areas: domination, access, diversity, and design. Flor noticed a lack of access and domination through inequalities and she embodied diversity as a Latina youth of poverty. Flor also addressed design, or suggestions to remedy the situation through laptop use in every classroom and also by circumventing obstacles with resourcefulness and persistence.

However, participants had none of Janks' (2010) four areas available during school or for homework. The children were dominated and controlled through autocratic testfocused curricula. They had little in-school access to digital literacy use, had few opportunities to express their communities' funds of knowledge and their diversity, and 
few design opportunities through inquiry-based projects. Yet, when these four areas are not present, the system can be bypassed. For instance, teen cell phone owners in the lowest SES are most likely to use their phones to go online (Lenhart, Ling, Campbell, \& Purcell, 2010): "The cell phone appears to be a viable alternative for internet access for some teens living in households that cannot afford computers" (para. 9). According to the adage, necessity is the mother of invention; people can use reconstruction and redesign to circumnavigate inequalities (Janks). In the next section, we theorize how participants circumvented a lack of access through personal relationships and ingenuity.

\section{Digital Literacy Access Outside of School}

Most participants in our study had home computers with high-speed Internet. Those without could not afford new machines or did not know where to go to get them repaired. However, Becker (2000) found only $22 \%$ of low SES children had access to home computers; perhaps the discrepancy lies in Becker's much larger sample size. Our findings also differ from those of Moje, Overby, Tysvaer, and Morris (2008), who surveyed, interviewed, and observed 716 participants, mostly low SES Latinos; most participants did not use the Internet outside of school. However, Moje et al. found those with Internet used it regularly. These two studies were published in 2000 and 2006 respectively; since then much has changed. In our own research, two families did not have working home computers and Internet in May 2010, but they had both a year later. Our results are consistent with those of Hutchinson and Henry (2010), who found students in low SES districts used the Internet more outside of school than in school. Also, Lenhart, Madden, and Hitlen (2005) found $73 \%$ of teen respondents with a family income of less than $\$ 30,000$ used the Internet; most went online from home.

The tutorial center appeared to have Thirdspace potential (Soja, 1996) and a technological metamorphosis. In 2010, only the director's office had Internet access, and the children only engaged in video games installed in the center's computers. By the following year, the center had become a place where digital literacy is embraced. Free $\mathrm{Wi}-\mathrm{Fi}$ is available throughout the center, many college tutors bring computers and engage the children in Internet-related instruction and tutoring, and the number of working computers has expanded, thanks to donations.

Furthermore, children in grade five and higher could engage in journal prompts focused on the relationship between global and local issues; staff members read responses and discussed them with the youth. We overheard staff commenting on what a youth wrote about the 2011 nuclear disaster in Japan, and their evaluative focus was not on lower-order concerns, but instead on the student's empathy and complex reasoning. Perhaps the staff believed children below grade five were too young for computers, but we believe all children are capable of constructing electronic responses. Even three-year olds are intentional writers (Harste, Woodward, \& Burke, 1984). Also, Pahl's and Rowsell's (2005) six-year old participant engaged in text-messaging and emailing by watching older siblings. Nevertheless, with the new journal prompts to choose from, tutorial children can express themselves freely, using digital literacy outside of a rigid testing environment permeating many low SES schools (Bussert-Webb, 2009c; Henry, 2007). 
Connecting local and global issues vis-à-vis prompts on the computer demonstrates how Thirdspace can break Firstspace and Secondspace binaries (Soja, 1996). The local could be conceptualized as Firstspace, or the informal sphere within Esperanza children's everyday lives, and the global could be Secondspace, or formal spheres outside of the colonia, such as state, national, and international news. According to Pahl and Rowsell (2005), the local and global can, and should, inform each other: "The link from local to global flows both ways and we recognize this quality when we watch the flow of texts across local and global sites" (p. 138). Thus, when staff members ask children to connect both spaces through electronic journal prompts, they are creating a Thirdspace. Furthermore, this is a safe space in which the children, all emergent bilinguals (García, Kleifgen, \& Falchi, 2008), are not judged by their written conventions.

Yet the tutorial center is connected to school as well, and it functions as a Thirdspace to bridge gaps for these "traditionally marginalized youth" (Frink et al., 2010, p. 75). In this center, local mothers prepare snacks for the children, and the director has a positive and intimate relationship with the community. Also, Esperanza children complete homework and are assisted by college students, tutorial staff, and other volunteers because most of the children's parents cannot help with the English-only homework (Díaz, 2011). The passionate Mexican-born tutorial director often contacts schools as the children's advocate, and is the bilingual and biliterate liaison between school and Esperanza parents, who may be embarrassed about gaps in their schooling or who may place complete confidence in school authorities (Valadez, 2011).

However, for this Thirdspace to transform practices and resources, the children need to be mentored, in and out of school, by people of all ages who engage in sophisticated uses of digital literacies (Frink, et al., 2010). Furthermore, the children must become the digital creators and actors who decide why, what, and how to construct meaning through challenging digital literacies; otherwise, they will end up replicating what Flor stated happened in school: "We do assignments they tell us to do," with a fillin-the-blank authority, e.g., tutor, staff member, preservice teacher, or mentor (Frink et al.).

Those who reported having no home computers used computers at the tutorial center or school, or at the homes of friends, neighbors, and extended family. Rideout, Foehr, and Roberts (2010) found one third of youth, between the ages of eight and 18, owned cell phones, but only one respondent in the present study owned one. About half accessed those of friends and families to call, text, play games, and to use other applications. Sharing digital literacies relates to other ways to communicate and to establish and maintain relationships. Resource sharing can be observed throughout the colonia, where one can see cords going from one home to another so neighbors can split electric bills. Also, when participants selected prizes after a plant scavenger hunt, we heard them say, "I'm getting this as a gift for my mom," and "This is for my sister." This type of sharing was a fund of knowledge. According to Moll (1992), funds of knowledge are not what people have, but instead what they do; they can be "latent, hidden knowledge, displayed in helping or teaching others" (p. 222).

Similarly, when Primeracomunión and Francisca asked Bussert-Webb to take their pictures and email the photos to them, they tapped into a social relationship to make and share meaning. They wanted people to see their images in their Facebook profiles and 
they accessed the iPhone of someone with more power or wealth. This reminds us of the rhizomic roots of ginger; if one part is cut off, other sides grow (Fernández, 2001). When they encountered barriers, participants found alternative paths to digital literacies. Furthermore, as they answered questions and participated in the think alouds, participants demonstrated how they got around costly games and monthly gaming frees. Their knowledge of free sites was an important finding because it demonstrates Janks' concept of design and creativity in the face of economic hardships. Digital literacies give us hope for children of poverty because of rhizomic opportunities to regenerate and to bypass obstacles. If fees precluded digital participation, low SES youth can find other paths, and they can do so in relationship with others.

\section{Digital Literacy Use Outside of School}

Most reported using digital literacies for non-academic purposes. This is contrary to the findings of Eamon (2004), based on a national sample of 1,029 10-14 year-olds. She discovered low SES youth were less likely to use computers for non-academic purposes than were their middle-class peers. Eamon concluded that African American and Latino parents are more likely to monitor their children's home computer use, but Rideout, Foehr, and Roberts (2010) found white parents were more likely to impose rules about media content. In the present study we had the impression parents were not aware of what their children were doing online, perhaps because their children used ICTs mostly in English. Since our case study is based on a small sample, we cannot generalize our data; we can only highlight the difference between our results and the findings of other studies.

Most mentioned accessing the Internet at home, but Warschauer and Matuchniak (2010) reported non-English speaking Latino/a youth have low rates of Internet access and use. Yet Rideout, Foehr, and Roberts (2010) found Latino/a and African American youth play video games approximately a half an hour more daily than do white youth, and that in 2009, Hispanics had higher computer usage rates than Whites in: social networking, instant messaging, video websites, emailing, reading magazines or newspapers, and using graphics and photos.

Some of our findings are similar to those of Warschauer and Matuchniak (2010), however. They state young Latinos/as of poverty tend to use digital literacies for more friendship-driven purposes rather than for interest-driven ones. These friendship-related practices involve "hanging out with their peers online" (p. 192), while interest-driven ones involve communicating, game playing, and sharing media. Warschauer and Matuchniak argue interest-related digital use requires special resources, such as broadband (versus modem) access, digital cameras, and camcorders. This is not the type of Internet use any of our participants mentioned engaging in, confirming they may lack the opportunity of being engaged in interest-driven digital literacies.

We were surprised only $15 \%$ literacy log respondents reported texting within 24hours; perhaps more did not text because only one owned a cell phone. Privacy may have been an issue. Conversely, perhaps the lack of texting related to respondents' young ages; $79 \%$ attended primary school, and only $21 \%$ were in middle school. Compared to the young ages of most of our respondents, most 16 to 25 year olds in a national sample texted daily; however, non-Hispanic youth, ages 16 to 17, texted $64 \%$ of the time, compared to $49 \%$ of Hispanic youth of the same ages (López \& Livingston, 2010). In 
their media study of different age groups (eight to 10,11 to 14 , and 15 to 18-year-olds), Rideout, Foehr and Roberts (2010) discovered a huge jump in total media usage among the 11- to 14-year-old group.

Another way to look at digital literacies is consumption versus creation. Most participants used digital literacies for texting, listening to music, and using Facebook and Myspace, and not creation (Attewell \& Winston, 2003). Additionally, less than half had homework involving computer use. Similarly, Rideout, Foehr, and Roberts (2010) found Hispanic youth spend more time using computers for recreation than white children do. Perhaps teachers believed the children did not have access to computers and to the Internet and did not want to penalize them if they were not able to complete these assignments. Warschauer and Matuchniak (2010) reported teacher respondents in highneed schools were reluctant to assign computer and Internet-related work.

Middle school respondents mentioned playing more games than primary school participants; however, the former used Facebook and e-mail primarily. Playing games instead of reading books is part of a larger debate. Gee (2007) argues students learn valuable print literacy skills and processes when they engage in video games and other ICTs; this type of literacy is not merely reading and writing print, but it includes diverse semiotic domains, such as images, symbols, graphs, or visual signs. In working through the levels of a complex game, Gee contends a person is decoding its "internal design grammar" (p. 29) which is a form of critical thinking.

Participants demonstrated creative ways they access digital literacies, but they appeared to be missing collaboration in affinity spaces. Gee $(2009,2011)$ describes Tabby Lou, an unemployed shut-in in her late sixties, who had two six-year-old, Simsplaying granddaughters; one needed a purple potty in Sims and Tabby Lou found a site online to design one. From the help of gamers of all ages, Tabby Lou eventually became an expert gamer and designer. In the present study, Frank played video the games more than any respondent. However, neither he nor others mentioned collaborating with other gamers or searching the Internet for help. Thus, none appeared to have been a part of online affinity spaces (Gee, 2011).

On the other side of the debate is Krashen (2004), who argues reading improvement is a result of uninterrupted engagement with continuous text. This assertion is supported by Moje, Overby, Tysvaer, and Morris (2008), who found participants' novel reading had a positive relationship with their overall academic achievement; however, the latter state: "The value of youths' out-of-school practices should not be assessed only by the influences of the practices on school achievement" (p. 149). Although we believe continuous aesthetic stances in story worlds help readers to become proficient and engaged over time (Wilhelm, 2008), we also recognize youth can use complex cognitive skills, similar to academic reading and writing, when they use digital literacies for nonacademic purposes (Moje et al., 2008), particularly when they engage in interest-driven driven digital literacy experiences (Warschauer \& Matuchniak, 2010) and create versus consume (Attewell \& Winston, 2003). Also, they could use game cheat sheets, which many gamers of complex video games contribute to and read. According to the Program for International Assessment (PISA) executive summary: 
Youth extensively engaged in online reading, such as reading e-mails, chatting on line, reading news on line, using an online dictionary or encyclopedia, participating in online group discussions and searching for information on line, are generally more proficient readers than students who do little online reading (OECD, 2010, p. 12).

Moreover, online reading comprehension relates to identifying questions, and locating, analyzing, synthesizing, and communicating information; also, children who struggle with print literacy but who soar in online reading comprehension may read online better than do those who fare better in offline reading but who lack online reading skills (Leu et al., 2007). The PISA findings cause us to ponder: "Whose interests are served by what these texts do" (Janks, 2010, p. 19)? Also, if the participants in the present study were mainly using new technologies for friendship and entertainment, were they reproducing structural inequalities? Why did teachers from high SES districts have significantly higher mean scores on online reading comprehension than teachers from low SES districts? (Henry, 2007).

\section{Limitations}

Several limitations came to light during this study. One limitation was evident during the process of interviewing children the first time. Because of the tight timeframe of the 2010 program and to make participants more comfortable, we interviewed two friends or siblings together. However, they may have copied information or agreed with the other interviewee so as not to appear as strange or different. Moreover, interviewing in the presence of peers might have diminished the researcher's role (Freeman \& Mathison, 2009). Thus, for the second round we interviewed each participant privately. Another methodological problem was we re-interviewed about half because many no longer attended the tutorial center. Although we could not do complete comparisons between the two sets of responses, the second interview did help us to corroborate findings.

Next, the first interview consisted of too many questions and topics, so we focused on digital literacies for the second round. Also, we should have asked how participants played games, as well as their use of game cheats, online collaboration, and web surfing to play better (Gee, 2011). Additionally, the two rounds of interviews and literacy logs are from self-reports and participant observations. Although we have had close contact with the mothers of many participants, for this facet of our study we did not ask the parents about digital literacies.

\section{Conclusions}

Many participants hungered for more technology-based projects. The digital work from school was just that, work. This type of authoritarian, reductionist curriculum for marginalized youth is a "reaction to globalized economies, polyglotal cultures, and massmediated childhoods" (Luke, 2005, p. xiii). Attempting to control what is perceived as an out-of-control situation has resulted in "educational fundamentalism" (p. xiii), or literal, more basic, and slower forms of literacy instruction. Some, such as Snow (2000), may contend that children's literacy skills are based on internal cognitive states, but Gee 
(2000a) argues we must consider societal factors. He posits success in the $21^{\text {st }}$ century relates to opportunities and relationships that affirm and extend children's digital and cultural identities.

It concerns us that most participants reported engaging in friendship- versus interest-driven technologies (Warschauer \& Matuchniak, 2010), and consumption versus creation (Attewell \& Winston, 2003). Also, the children's interest in digital literacies may indicate the need to provide them with more computer-related projects, versus the testand worksheet-driven curricular focus they described and that Bussert-Webb (2009c) found in a nearby school with a similar SES and ethnic population. According to Leu, O'Byrne, et al. (2009), "Students who most need to be prepared at school for an online age of information are precisely those who are being prepared the least" (p. 267). Standardized skills can be performed at low-cost centers for people who have minimum wage jobs, but to be successful in the future, people must be innovative, passionate, persistent, and collaborative. Online affinity spaces allow for these things to happen (Gee, 2011).

Thus, providing culturally diverse children of poverty with more challenging and interesting computer games in and out of school may help their ever-changing critical thinking and reading skills (Gee, 2007). Also, youth can be hooked into print literacy when they are exposed to more video games in which they become creators, not just consumers (Attewell \& Winston, 2003). An example is Scribblenauts; in this DS game a player can create scenes by typing words with a keyboard and tapping on the bottom screen. The creator can add and delete people, things, and places and can have them interact on the top screen (John, 2009).

This is not to say schools should engage in only digital literacies for entertainment. Indeed, educational purposes should take precedence (O'Brien \& Scharber, 2008). Teaching children how to locate, summarize, and evaluate online information critically, and to make and share meaning through online reading and writing, should be done at all schools (Leu, O’Byrne, et al., 2009). For example, Canadian teachers involved Aboriginal high school students in generative digital narratives: "Engaging students required tapping their interest in using electronic media, accepting their lived experiences, and inviting them to use their funds of knowledge in multiliteracies" (Pirbhai-Illich, 2010, p. 264).

Similarly, Warschauer and Ware (2008) describe Project Fresa, which focused on harsh working conditions in California strawberry fields. Two teachers designed the project with elementary students, $80 \%$ of whom were Latinos/as. The students generated survey and interview questions; conducted interviews; created spreadsheets, graphs, and charts to re-present their findings; and emailed elected officials and strawberry growers about their concerns. They exchanged emails with Puerto Rican children who lived in coffee-growing regions and also presented findings to community members and parents. The children used digital literacies as a critical inquiry tool throughout the project. They did not email Christmas lists, decontextualized from the curriculum, nor did they use computers to take AR tests to receive prizes. Instead, they were engaged in meaning making and design (Janks, 2010) through digital literacies. The use of machines was not the goal. Rather, machines facilitated semiotic processes and collaboration. 
However, some children may be resistant to the technologies teachers want them to use (Cuban, 2001) and may perceive technology-related projects as mere tasks. Rish and Caton (2009) describe successes and failures using collaborative digital literacy projects in their high school classrooms. Students researched human rights violations and created public service announcements with sound bites, digital images, and videos, yet most delegated the work. Others used a classroom wiki to create a fictional world, but some wrote and interacted minimally. Thus, teachers and district personnel could discover what types of technologies youth enjoy using, and should ask the students how and whether "their online literacies should be embraced in the regular curriculum" (Alvermann, 2008, p. 18). By listening to students' responses, both in- and out-of-school, digital technology practices could inform each other (Leu, O'Byrne, et al., 2009).

It is important for educators to affirm youths' literacy practices and identities to keep their academic interests because many feel a disconnection between school and their digital lives outside of school (Alvermann, 2008). When this recognition happens, instructors can see students who struggle with traditional print literacy from a strengthbased perspective (González, Moll, \& Amanti, 2005). O’Brien and Scharber (2008) posit the home versus school dichotomy is a false binary and that digital literacies can bridge this gap. Instead of Thirdspace taking place outside of school only, as in the tutorial center of the present study, it is possible for classrooms to be spaces in which digital technologies are embraced in generative, transformative practices. Moje et al. (2004) argue teachers can value and build upon students' funds of knowledge and Discourses to create a Thirdspace in which classroom texts are interpreted. O'Brien and Scharber state: "The possibilities of digital literacies relate to bridging the new with the old in ways that will gradually transform the ways youth express ideas and learn in schools ..." (p. 67).

Based on our own children who attended area public primary schools for several years, many technology teachers in these schools are teacher aides who have children read test passages and click on the correct answers; some use only installed reading programs. This test-focused milieu may have been why Artista wanted reading passages on the computer. Also, most local primary school children have a technology class once weekly. However, a plethora of computers and other types of classroom equipment on campuses are never used (Cuban, 2001). Again, much of these practices relate to the testing environment in low SES schools.

Perhaps most participants' teachers had little knowledge and skills in instructional technology, so they rarely had the children use it for complex projects. Several reports demonstrate educators do not always feel comfortable and knowledgeable in integrating instructional technology (Rakes \& Casey, 2002). Only one participant in Stolle's study (2008) tried something beyond her understanding: podcasts. However, this teacher was not comfortable with podcasts and did not do much with them. Stolle concludes: "The world is being changed by people who are exploring new envisionments or possibilities with the digital technologies and electronic networks. But, the teachers in my study do not seem to be the people pushing for this change, or probing toward new envisionments" (p. 66).

A lack of technology integration is particularly marked among teachers in lowincome urban schools because of the test preparation focus vis-à-vis the No Child Left Behind Act (Henry, 2007; U.S. Department of Education, 2002). Rish and Caton (2009) 
engaged students in participatory, collaborative, and generative digital technology projects. However, they taught in rural high schools, serving mostly white middle-class students. Furthermore, the fantasy and science fiction English electives course Caton taught was free of graduation requirements and state assessment pressures. Thus, it is much easier to implement new literacy practices sans pressure. Hopefully, if U.S. President Obama's proposals are accepted by Congress, teachers in high-need districts will get more technology training and mentoring, and testing will focus on higher-order skills and problem solving (U.S. Department of Education, 2010).

However, the Obama proposal does not include online reading comprehension. Indeed, online reading and writing are not assessed in any state-level public school test, nor was online reading comprehension part of the National Assessment of Educational Progress (NAEP) framework for 2009, meaning these skills will not be part of the national test until 2019 (Leu, McVerry, et al., 2009). Policies stipulating major shifts in literacy education and assessment "will affect teacher education, professional development, and classroom teaching, moving education forward into the $21^{\text {st }}$ century" (O’Brien \& Scharber, 2008, p. 67).

Some educators assume children of poverty do not have access and thus limit technology-based assignments, but they should ask if students have high-speed Internet and computers available outside of school. If the children do not, campuses could provide time before or after school for generative, technology-based assignments. It is our hope this article begins to change a dangerous misperception about the digital literacy access of children of poverty. The problem is not about access, but about use; the children were not mentored or challenged to take their digital technology uses to the next level. Teachers, preservice teachers, professors, tutorial staff, and others can teach children how to use digital technology in complex ways, but legislation must also change so educators have the training, mentoring, and time to incorporate contextualized, challenging digital technology practices.

More in-depth research is needed on the digital technology practices among low SES children, but our findings make us uneasy. The digital divide for many of the 28 participants was enormous because of how they used digital technology; this use relates to underlying social practices (Street, 2003). Also, structural inequalities relate to schooling (Enterline et al., 2008). However, the children's underlying social practice of sharing and ingenuity also demonstrated hope. Wherever people are oppressed, be it U.S. colonias, South African townships, or Native American reservations, people will find ways to circumvent inequalities through design and redesign (Janks, 2010).

As Soja (2011) states, spaces we create can be unfair and unjust. As we listened to his descriptions of inadequate bus routes in urban Los Angeles, we pondered why Esperanza residents had no nearby bus routes and how participants' schools did not invite them to design and redesign with digital technology. Yet, we have the power to make spaces more just. A coalition sued (and won) the city of Los Angeles on civil rights grounds because a new bus route discriminated against transportation-dependent people. In some neighborhoods, such as the one in Los Angeles, "there is little access to other spaces due to poor transport links and low economic status. However, through email and the web, children can gain access to global spaces and meanings" (Pahl \& Rowsell, 2005, p. 138). Perhaps one day Esperanza can be incorporated and its children will experience 
equitable levels of digital technology use in and out of school. On a positive note, the tutorial center appears to be moving toward a Thirdspace for transformative digital literacy practices. This Thirdspace can be during the school day, also, to provide systemic changes affecting this population. After all, education should involve space for the "practice of freedom" (Freire, 1976).

\section{References}

Alvermann, D. E. (2008). Why bother theorizing adolescents' online literacies for classroom practice and research? Journal of Adolescent \& Adult Literacy, 52(1), 819.

Attewell, P., \& Winston, H. (2003). Children of the digital divide. In P. Attewell \& N.M. Seel (Eds.), Disadvantaged teens and computer technologies (pp. 117-136). Münster, Germany: Waxmann.

Barton, D., \& Hamilton, M. (1998). Local literacies: Reading and writing in one community. London, UK: Routledge.

Becker, H. J. (2000). Who's wired and who's not: Children's access to and use of computer technology. The Future of Children, 10(2), 44-75.

Bogdan, R. C., \& Biklin, S .K. (2007). Qualitative research for education: An introduction to theory and methods (5th ed.). Boston, MA: Allyn \& Bacon.

Brenner, C. T., Coronado, I., \& Soden, D. L. (2003). The U.S. Census 2000 and "colonias" along the U.S.-Mexico border: An anthropological approach. In Dígame! Policy and politics on the Texas border (pp. 275-293). Dubuque, IA: Kendall/Hunt Publishing Company.

Bussert-Webb, K. (2008, Fall). Gardening hope: How a tutoring and native garden project impacted preservice teachers. The Journal for Civic Commitment, 11. Retrieved May 18, 2011, from http://www.mesacc.edu/other/engagement/Journal/index11.shtml

Bussert-Webb, K. (2009a). Community SL impact: Tutees and walkers. Academic Exchange Quarterly, 13(3), 65-70.

Bussert-Webb, K. (2009b). Gardening, tutoring, and service by and for Latinos: La Esperanza. Education Research and Perspectives, 36(2), 81-109.

Bussert-Webb, K. (2009c). ¿Qué hago? Latino/a children describe their activities in an "exemplary" school. Journal of Latinos and Education, 8(1), 38-54.

Cuban, L. (2001). Oversold and underused: Computers in the classroom. Cambridge, MA: Harvard University Press.

Damico, J. S., \& Baildon, M. C. (2007). Examining the ways readers engage with Web sites during Think Aloud sessions. Journal of Adolescent and Adult Literacy, 51(3), 254-263.

Díaz, M. E. (2011). A case study of Spanish language use in a Texas border colonia. Unpublished doctoral dissertation, The University of Texas at Brownsville, Brownsville.TX.

Eamon, M. K. (2004). Digital divide in computer access and use between poor and nonpoor youth. Journal of Sociology and Social Welfare, 31(2), 91-112. 
Enterline, S., Cochran-Smith, M., Ludlow, L.H., \& Mitescu, E. (2008). Learning to teach for social justice: Measuring change in the beliefs of teacher candidates. New Educator, 4(4), 267-290.

Fernández, R. (2001). Imagining literacy: Rhizomes of knowledge in American culture and literature. Austin, TX: University of Texas Press.

Freeman, M., \& Mathison, S. (2009). Researching children's experiences. New York, NY: Guilford Press.

Freire, P. (1970). Pedagogy of the oppressed. Harmondsworth, England: Penguin.

Freire, P. (1976). Education, the practice of freedom (2nd ed.) (M. B. Ramos, Trans.) London, UK: Writers and Readers Publishing Cooperative.

Frink, J., Ares, N., Mukhopadhyay, K., \& Tsoumani, E. (2010). Hybridity and transformation: Social spaces and youth cultural practices. In N. Ares (Ed.), Youth-full productions: Cultural practices and constructions of content and social spaces. New York, NY: Peter Lang.

García, O., Kleifgen, J.A., \& Falchi, L. (2008). From English language learners to emergent bilinguals.. Equity Matters: Research Review No. 1. New York, NY: The Campaign for Education Equity, Teachers College, Columbia University. Retrieved October 11, 2008, from http://www.tc.columbia.edu/i/a/document/6468_Ofelia_ELL_Final.pdf

Gee, J. P. (2000a). The limits of reframing: A response to Professor Snow. Journal of Literacy Research, 32(1), 121-130.

Gee, J. P. (2000b). The New Literacy Studies: From "socially situated" to the work of the social. In D. Barton, M. Hamilton, \& R. Ivanic (Eds.), Situated literacies: Reading and writing in context (pp. 180-196). London, UK: Routledge.

Gee, J. P. (2007). What video games have to teach us about learning and literacy (2nd ed.). New York, NY: Palgrave.

Gee, J. P. (2008). Social linguistics and literacies: Ideology in discourses (3rd ed.). New York, NY: Routledge.

Gee, J. P. (2009). The purple potty theory of passion. Phoenix, AZ: Author. Retrieved May 25, 2011, from http://breakthroughlearning.blogspot.com/2009/10/purplepotty-theory-of-passion.html

Gee, J. P. (2011, April). On spatial grounds: Critical geography and education research for social justice. Presidential session. Paper presented at the annual meeting of the American Educational Research Association, New Orleans, LA.

Glaser, B., \& Strauss, A. (1967). The discovery of grounded theory. New York, NY: Aldine Press.

González, N., Moll, L., \& Amanti, K. (Eds.). (2005). Funds of knowledge: Theorizing practices in households, communities and classrooms. Mahwah, NJ: Lawrence Erlbaum Associates Publishers.

Gorski, P. (2008). Peddling poverty for profit: Elements of oppression in Ruby Payne's framework. Equity and Excellence in Education, 41(1), 130-148.

Greenberg, J. B. (1990). Funds of knowledge: Historical constitution, social distribution, and transmission. In W.T. Pink, D.S. Ogle, \& B.F. Jones (Eds.), Reconstructing to promote learning in America's schools: Selected readings (pp. 317-326). Elmhurst, IL: North Central Regional Educational Laboratory. 
Harste, J. C., Woodward, V. A., \& Burke, C. L. (1984). Language stories and literacy lessons. Portsmouth, NH: Heinemann.

Henry, L.A. (2007). Exploring new literacies pedagogy and online reading comprehension among middle school students and teachers: Issues of social equity or social exclusion? Dissertations Collection for University of Connecticut. Paper AAI3282520. Retrieved May 29, 2011, from http://digitalcommons.uconn.edu/dissertations/AAI3282520/

Hutchison, A., \& Henry, L. (2010). Internet use and online reading among middle grade students at risk of dropping out of school. Middle Grades Research Journal, 5(2), 61-75.

Janks, H. (2010). Literacy and power. New York, NY: Routledge.

John, T. (2009). How innovative Scribblenauts recognizes 10,000 different words. Wired. Retrieved November 2, 2010, from http://www.wired.com/gamelife/2009/06/scribblenauts

Kalantzis, M. (2011, April). The New London agenda in retrospect. Presidential session: Beyond New London: Literacy learning and the design of social futures. Paper presented at the Annual Meeting of the American Educational Research Association, New Orleans, LA.

Karchmer, R. A., Mallette, M. H., Kara-Soteriou, J., \& Leu, D.J., Jr. (Eds.). (2005). Innovative approaches to literacy education: Using the Internet to support new literacies. Newark, DE: International Reading Association.

Krashen, S. (2004). The power of reading: Insights from the research. Portsmouth, NH: Heinemann.

Lankshear, C., \& Knobel, M. (2006). New literacies: Everyday practices and classroom learning (2nd ed.). New York, NY: Open University Press.

Lazarus, W., Wainer, A., \& Lipper, L. (2005). Measuring digital opportunity for America's children: Where we stand and where we go from here. Santa Monica, CA: Children's Partnership. Retrieved December 16, 2010, from http://www2.ucsc.edu/cjtc/docs/dd_highlights.pdf

Lenhart, A., Ling, R., Campbell, S., Purcell, K. (2010). Teens and mobile phones. Washington, D.C.: Pew Internet \& American Life Project. Retrieved December 8, 2011, from http://pewinternet.org/Reports/2010/Teens-and-MobilePhones/Chapter-2/Part-4.aspx

Lenhart, A., Madden, M., \& Hitlen, P. (2005). Teens and technology: Youth are leading the transition to a fully wired and mobile nation. Washington, DC: Pew Internet \& American Life Project. Retrieved May 23, 2011, from http://www.pewinternet.org/ /media//Files/Reports/2005/PIP_Teens_Tech_July200 5web.pdf.pdf

Leu, D. J., McVerry, J. G., O’Byrne, W. I., Zawilinski, L., Castek, J., \& Hartman, D. K. (2009). The new literacies of online reading comprehension and the irony of No Child Left Behind: Students who require our assistance the most, actually receive it the least. In L. M. Morrow, R. Rueda, \& D. Lapp (Eds.), Handbook of research on literacy instruction: Issues of diversity, policy, and equity (pp. 173-194). New York, NY: Guilford Publications. 
Leu, D. J., O’Byrne, W. I., Zawilinski, L., McVerry, J. G., \& Everett-Cacopardo, H. (2009). Comments on Greenhow, Robelia, and Hughes: Expanding the new literacies conversation. Educational Researcher, 38(4), 264-269.

Leu, D. J., Zawilinski, L., Castek, J., Banerjee, M., Housand, B., Liu, Y., \& O’Neil, M. (2007). What is new about the new literacies of online reading comprehension? In L. Rush, J. Eakle \& A. Berger (Eds.), Secondary school literacy: What research reveals for classroom practices (pp. 37-68). Urbana, IL: National Council of Teachers of English.

Long, G. (2010, July 31). TEA: District recognized; all 52 schools recognized or exemplary. The Brownsville Herald. Retrieved October 4, 2010, from http://www.brownsvilleherald.com/articles/recognized-114910-districtmorning.html

López, M. H., \& Livingston, G. (2010). How young Latinos communicate with friends in the digital era. Washington, D.C.: Pew Hispanic Center. Retrieved December 3, 2010, from http://pewresearch.org/pubs/1680/young-latinos-communicate-cellphone-text-message-native-foreign-born

Luke, A. (2005). Foreward. In Pahl, K. \& Rowsell, J, (Eds.). Literacy and education: Understanding the new literacy studies in the classroom (pp. $\mathrm{x}$-xiii). London, UK: Paul Chapman.

Moje, E. B., Ciechanowski, K. M., Kramer, K., Ellis, L., Carrillo, R., \& Collazo, T. (2004). Working toward third space in content area literacy: An examination of everyday funds of knowledge and discourse. Reading Research Quarterly 39(1), 38-70.

Moje, E. B., Overby, M., Tysvaer, N., \& Morris, K. (2008). The complex world of adolescent literacy: Myths, motivations, and mysteries. Harvard Educational Review, 78(1), 107-154.

Moll, L. C. (1992). Literacy research in community and classrooms: A sociocultural approach. In R. Beach, J. Green, M. Kamil, \& T. Shannahan (Eds.), Multidisciplinary perspectives in literacy research (pp. 211-244). Urbana, IL: National Conference on Research in English.

Oakes, J. (2005). Keeping track: How schools structure inequality. (2nd ed.). New Haven, CT: Yale University.

O'Brien, D., \& Scharber, C. (2008). Digital literacies. Journal of Adolescent and Adult Literacy, 52(1), 66-68.

OECD. (2010). PISA 2009 results: Executive summary. Paris, France: Program for International Assessment (PISA), Organization for Economic Co-operation and Development (OECD).

Pahl, K., \& Rowsell, J, (2005). Literacy and education: Understanding the new literacy studies in the classroom. London, UK: Paul Chapman.

Parsad, B., Jones, J., \& Greene, B. (2005). Internet access in U.S. public schools and classrooms: 1994-2003. U. S. Department of Education. Washington, D.C.: National Center for Educational Statistics. Retrieved August 30, 2011, from http://nces.ed.gov/pubs2005/2005015.pdf

Pirbhai-Illich, F. (2010). Aboriginal students engaging and struggling with critical multiliteracies. Journal of Adolescent \& Adult Literacy 54(4), 257-266. 
Rakes, G. C., \& Casey, H. B. (2002). An analysis of teacher concerns toward instructional technology. International Journal of Educational Technology, 3(1). Retrieved December 7, 2011, from http://www.ed.uiuc.edu/ijet/v3n1/rakes/index.html

Rideout, V. J., Foehr, U.G., \& Roberts, D.F. (2010). Generation $M^{2}$ : Media in the lives of 8- to 18-year olds. Menlo Park, CA: Henry J. Kaiser Family Foundation. Retrieved May 30, 2011, from http://www.kff.org/entmedia/upload/8010.pdf

Rish, R., \& Caton, J. (2009). Complexities of teaching new literacies in our classrooms. Adolescent Literacy in Practice, November/December. Retrieved August 6, 2011, from http://kennesaw.academia.edu/RyanRish/Papers/226891/Complexities_of_Teaching _New_Literacies_in_Our_Classrooms

Skudowitz, J. (2009). Research report: A case study of the digital literacy practices in a grade 10 English classroom at a private school. Unpublished Master Thesis, University of the Witwatersrand, Johannesburg, South Africa. Retrieved May 23, 2011,

from http://wiredspace.wits.ac.za/bitstream/handle/10539/5938/9807639HMAResearchR eport2008.pdf?sequence $=1$

Snow, C. E. (2000). On the limits of reframing: Rereading the National Academy of Sciences Report on Reading. Journal of Literacy Research, 32(1), 113-120.

Soja, E.W. (1996). The trialectics of spatiality. In E.W. Soja (Ed.), Thirdspace: Journeys to Los Angeles and other real-and-imagined places (pp. 54-82). Cambridge, MA: Blackwell.

Soja, E. W. (2010). Seeking spatial justice. Minneapolis, MN: University of Minnesota Press.

Soja, E. W. (2011, April). On spatial grounds: Critical geography and education research for social justice. Presidential session. Paper presented at the annual meeting of the American Educational Research Association, New Orleans, LA.

Stolle, E. P. (2008). Teachers, literacy, and technology: Tensions, complexities, conceptualizations, and practice. In Y. Kim, V. J. Risko, D. L. Compton, D. K. Dickinson, M. K. Hundley, R. T. Jiménez, et al. (Eds.), 57 ${ }^{\text {th }}$ Yearbook of the National Reading Conference (pp. 56-69). Oak Creek, WI: National Reading Conference.

Street, B. V. (1993). Introduction: The New Literacy Studies. In B. Street (Ed.), Crosscultural approaches to literacy (pp. 1-21). Cambridge, UK: Cambridge University Press.

Street, B. V. (2003). What's new in new literacy studies? Current Issues in Comparative Education, 5(2), 1-14.

Street, B.V., \& Lefstein, A. (2007). Literacy: An advanced resource book. Oxon, OH: Routledge.

Texas Secretary of State (2010). Colonias FAQs (frequently asked questions). Austin, TX: Author. Retrieved August 12, 2010, from http://www.sos.state.tx.us/border/colonias/faqs.shtml 
U.S. Census Bureau (2000). American Fact Finder. Washington, D.C.: United States Census Bureau. Retrieved April 17, 2009, from http://factfinder.census.gov/home/saff/main.html? lang=en

U.S. Census Bureau (2010). Income, poverty, and health insurance coverage in the United States: 2009. Report P60, n. 238, Table B-2, pp. 62-7. Retrieved August 12, 2011, from http://www.census.gov/prod/2010pubs/p60-238.pdf

U.S. Department of Education (2002). Public Law 107-110, $107^{\text {th }}$ Congress. No Child Left Behind Act of 2001.Washington, D.C.: Author. Retrieved September 14, 2009, from http://www2.ed.gov/policy/elsec/leg/esea02/107-110.pdf

U.S. Department of Education (2010). Supporting science, technology, engineering, and mathematics education: Reauthorizing the Elementary and Secondary Education Act. Washington, D.C.: Author. Retrieved October 22, 2011, from http://www2.ed.gov/policy/elsec/leg/blueprint/faq/supporting-stem.pdf

U.S. Department of Housing and Urban Development (2005). Boosting efficiency in colonia homes. Washington, D.C.: PATH: Partnership for Advancing Technology in Housing, U.S. Department of Housing and Urban Development. Retrieved, May 22, 2010, from http://www.pathnet.org/si.asp?id=2658

Valadez, C. M. (2011). Saving La Nena. In M. L. Reyes (Ed.), Words were all we had: Becoming biliterate against the odds. New York, NY: Teachers College Press.

Warschauer, M. \& Matuchniak, T. (2010). New technology and digital worlds: Analyzing evidence of equity in access, use, and outcomes. Review of Research in Education, 34(1), 179-225.

Warschauer, M., \& Ware, P. (2008). Learning, change, and power. In J. Coiro, M. Knober, C. Lankshear, \& D. J. Leu, (Eds.), Handbook of research on new literacies (pp. 215-239). New York, NY: Lawrence Erlbaum Associates.

Wilhelm, J.D. (2008). You gotta be the book: Teaching engaged and reflective reading with adolescents (2nd ed.). New York, NY: Teachers College Press.

\section{Author Biographies}

Kathy Bussert-Webb is Associate Professor and Graduate Reading Program Coordinator in the College of Education at the University of Texas Brownsville. Her research interests include digital, disciplinary, and community literacies.

María E. Díaz is Adjunct Professor in the College of Education at the University of Texas-Brownsville. Her research interests include biliteracy, family literacy practices, and digital literacy. 